Research Article

\title{
Impact of Ridge-Furrow Planting in Pakistan: Empirical Evidence from the Farmers Field
}

\author{
Imtiaz Hussain (D), ${ }^{1}$ Akhter Ali, ${ }^{1}$ Ansaar Ahmed, ${ }^{2}$ Hafiz Nasrullah, ${ }^{3}$ \\ Badar ud Din Khokhar, ${ }^{4}$ Shahid Iqbal, ${ }^{5}$ Azhar Mahmood Aulakh, \\ Atta ullah Khan, ${ }^{7}$ Jamil Akhter, ${ }^{8}$ and Gulzar Ahmed ${ }^{9}$ \\ ${ }^{1}$ CIMMYT, CSI, NARC, Park Road, Islamabad, Pakistan \\ ${ }^{2}$ CIMMYT, Cereal Crop Research Institute, Nowshera, Pakistan \\ ${ }^{3}$ Agronomic Research Station, Bahawalpur, Pakistan \\ ${ }^{4}$ Wheat Research Institute Sindh, Sakrand, Pakistan \\ ${ }^{5}$ Agriculture Research Institute, DI Khan, Pakistan \\ ${ }^{6}$ Arid Zone Research Institute, Bhakkar, Pakistan \\ ${ }^{7}$ Arid Zone Research Institute, Umerkot, Pakistan \\ ${ }^{8}$ National Rural Support Program, Islamabad, Pakistan \\ ${ }^{9}$ Cereal Crop Research Institute, Nowshera, Pakistan \\ Correspondence should be addressed to Imtiaz Hussain; i.hussain@cgiar.org
}

Received 25 January 2018; Revised 19 April 2018; Accepted 8 May 2018; Published 2 July 2018

Academic Editor: Manuel Tejada

Copyright ( $\odot 2018$ Imtiaz Hussain et al. This is an open access article distributed under the Creative Commons Attribution License, which permits unrestricted use, distribution, and reproduction in any medium, provided the original work is properly cited.

Wheat is planted through the broadcast method on 7.8 million ha and irrigated through low-efficiency flood basin irrigation methods. With decreased water availability, there is a need to adopt water use efficient planting techniques. The current paper uses two-year trials data set as well as farmer survey data to demonstrate benefits of ridge-furrow planting wheat and farmer perception regarding the technology in Pakistan. During 2014-15 and 2015-16, ridge-furrow planting of wheat was compared with farmer practice of planting on flat surface through broadcasting at 162 sites located in 15 districts of Pakistan. In a survey, 134 farmers shared their experiences about ridge-furrow planting. Data collected from field trials and demonstrations showed that better tillering and crop growth contributed towards $12 \%$ higher wheat grain yield with ridge-furrow planting in comparison with the farmer practice of flat planting in all 15 districts during both years. Furrow-irrigated ridge planting of wheat helped farmers in saving of 30-35\% water in comparison with farmer practice. Farmers adopting ridge-furrow wheat planting earned USD 100.63 per hectare more profit than nonadopter farmers. Adoption of this technology on one million hectare can help in saving 1 million acre foot of water and produce additional 0.36 million tons of wheat per year.

\section{Introduction}

Agriculture sector employs about $42.3 \%$ of the labor force and contributes about $19.5 \%$ to the GDP (gross domestic product) of Pakistan [1]. The total cultivated area is 22.12 million hectares, and out of this, 19.23 million hectares are being irrigated through various sources [1]. In Pakistan, 5.96 million hectares are irrigated through canals, whereas the rest of $8.15,3.71$, and 0.65 million hectares are irrigated through canal tube wells, tube wells, and wells, respectively [1].
Wheat, a major staple food crop, planted on more than 9.22 million hectares during $2015-16$ contributed $1.9 \%$ to GDP [1]. Wheat is generally planted by the broadcast method [2-4] during rabi season in irrigated areas of Pakistan, and drill sowing is minimal. Irrigated wheat covers 8 million hectare area that accounted for $85 \%$ of the total wheat area with an average productivity of $3.0 \mathrm{t} / \mathrm{ha}$.

In Pakistan, water availability in the normal year for $r a b i$ season was around 36.9 MAF. During the last decade (2007-08 to 2016-17), water availability for rabi season was 
$5-45 \%$ lower in comparison with the normal year [1]. In canal-irrigated areas, farmers get fixed turn time to irrigate crop once in a week [3], which is not enough to irrigate their whole cropped area, and generally rely on either tube well water or rainfall. Majority of the wheat area is irrigated through flood or the basin irrigation method [3] which has $30-50 \%$ irrigation efficiency. Because of uncertainty and limited water availability at critical growth stages, farmers tend to apply too much water to the wheat crop when available, which also affects the wheat growth negatively. Availability of water is reducing, and there is a need to adopt water-saving techniques.

Furrow-irrigated raised bed technology is one of the efficient irrigation methods in which water moves in furrow, and crop is planted on raised beds. In the Yaqui Valley of Mexico, farmers have shifted to a bed and furrow system for wheat planting due to scarcity of water [5]. The technique resulted improvement in irrigation and nutrient management, saving in water, better crop stand, lower seed rate, and reduction in lodging [5]. Bed and furrow planting systems improved water distribution [6], reduced water requirement for irrigation, improved water use efficiency in the ricewheat cropping system of Indo-Gangetic plains $[7,8]$, and provided drainage in water logged fields [5]. Raised bed planting provides an opportunity for mechanical weed control, permits band application of fertilizers, improves nitrogen use efficiency, and reduces crop lodging [9-12]. Selection of the variety is also important in raised bed planting. Wheat varieties with the broad leaf area and ground cover had higher grain yield in comparison with upright and compact structure varieties lower in bed planting [10].

Raised bed planting under the ZT condition in maizebased systems had $13-28 \%$ higher system productivity and net return of USD 312 ha-1 in comparison with the conventional planting system [13]. Integration of short duration mung bean crop in the maize-wheat system on permanent beds enhanced the system productivity by $29 \%$, net returns by $38 \%$, and water productivity by $24 \%$ compared to the conventional system [14].

In Pakistan, wheat sown on $70 \mathrm{~cm}$ bed and furrow system in the rice-wheat area of Punjab produced good yields due to better spike length, number of grains per spike [15]. Mollah et al. [16] studied the raised bed planting method of wheat in Bangladesh and found higher wheat productivity by planting wheat on a $70 \mathrm{~cm}$ bed in the rice-wheat cropping system. Waraich et al. [17] found an increase of 18-45\% higher WUE (water use efficiency) without yield increase under bed planting with furrow irrigation in comparison with conventional flat planting with flood irrigation.

Water Management Research Center at University of Agriculture, Faisalabad, introduced bed and furrow planter to plant four wheat rows on a $90 \mathrm{~cm}$ bed and furrow system [11], and the results showed around $49 \%$ saving in irrigation water timing and $18 \%$ higher yield with raised bed planting in comparison with flat sowing $[11,18,19]$. Adopting farmers had benefit of Rs.17000/ha and 50\% saving in water with an additional cost of Rs.1350/ha [20]. PARC in collaboration with ACIAR planted 7 rows of wheat or 2 rows of maize on the $180 \mathrm{~cm}$ bed and furrow and observed $30-32 \%$ increase in grain yield and water saving [21].

In wheat-based systems, wheat is planted after rice/cotton/sugarcane/maize in Pakistan. Presence of previous crop residue hampers tillage and seeding operations for wheat. This had a negative effect on adoption of drill and bed planting techniques, and in resultant, majority of farmers are forced to plant wheat through the broadcast method with heavy tillage. In ridge-furrow planting of maize and cotton, ridge and furrows formed with a ridger and cotton or maize planted manually on the top or the side of the ridge increased germination and yield of cotton in comparison with flat planting [22] and is widely practiced in Pakistan.

Ridge planting was evaluated in comparison with bed planting and drill sowing, and $17-24 \%$ higher wheat yield was observed with bed panting in comparison with the conventional method of broadcasting. Raised bed and ridge sowing methods of wheat planting saved $22 \%$ irrigation water over flat sowing [23]. In the WPEP (Wheat Productivity Enhancement Program) project, ridge planting was evaluated for wheat planting and ridge planting of wheat had an improvement of $23 \%$ in yield and $40 \%$ in saving of irrigation water in comparison with the farmer's technique of broadcasting [24].

The ridge-furrow planting comprises land preparation, broadcasting of seed, and formation of ridges and furrow with the ridger, while the farmer's practice includes land preparation and broadcasting of the seed and shallow cultivation with the cultivator and planking. Bed or ridge planting of wheat is being adopted across all the four provinces in Pakistan, that is, Punjab, Sindh, Khyber Pakhtunkhwa (KP), and Balochistan. Keeping in view the advantage of technology and availability of ridgers with farmers, ridge-furrow planting of wheat was widely evaluated in farmers' fields in various districts of the wheat cropping system of Pakistan.

The main purpose of the current paper was to document the impact of the raised bed/ridge planting technology by using two types of data set, that is, field trials data set and the data set collected from the farmers. The rest of the paper is presented in two more sections that included methodology and empirical results with discussion and conclusions. The current paper has many novel aspects as the results are also verified across different data sets and are consistent and robust.

\section{Materials and Methods}

The paper uses integrated approaches to document the evidences of ridge-furrow planting of wheat technology, that is, one from the field evaluation or demonstration data and the other from the farmer perception through survey. From the field, two years trails were conducted and the data were collected from the sites comparing the ridge-furrow planting of wheat with farmers practice. Field evaluation of ridgefurrow planting in comparison with farmer practice was conducted on a total of 162 farmer fields and research farms that included 68 sites in 2014-15 and 94 sites in the 2015-16 wheat season. These farms were located in districts of 


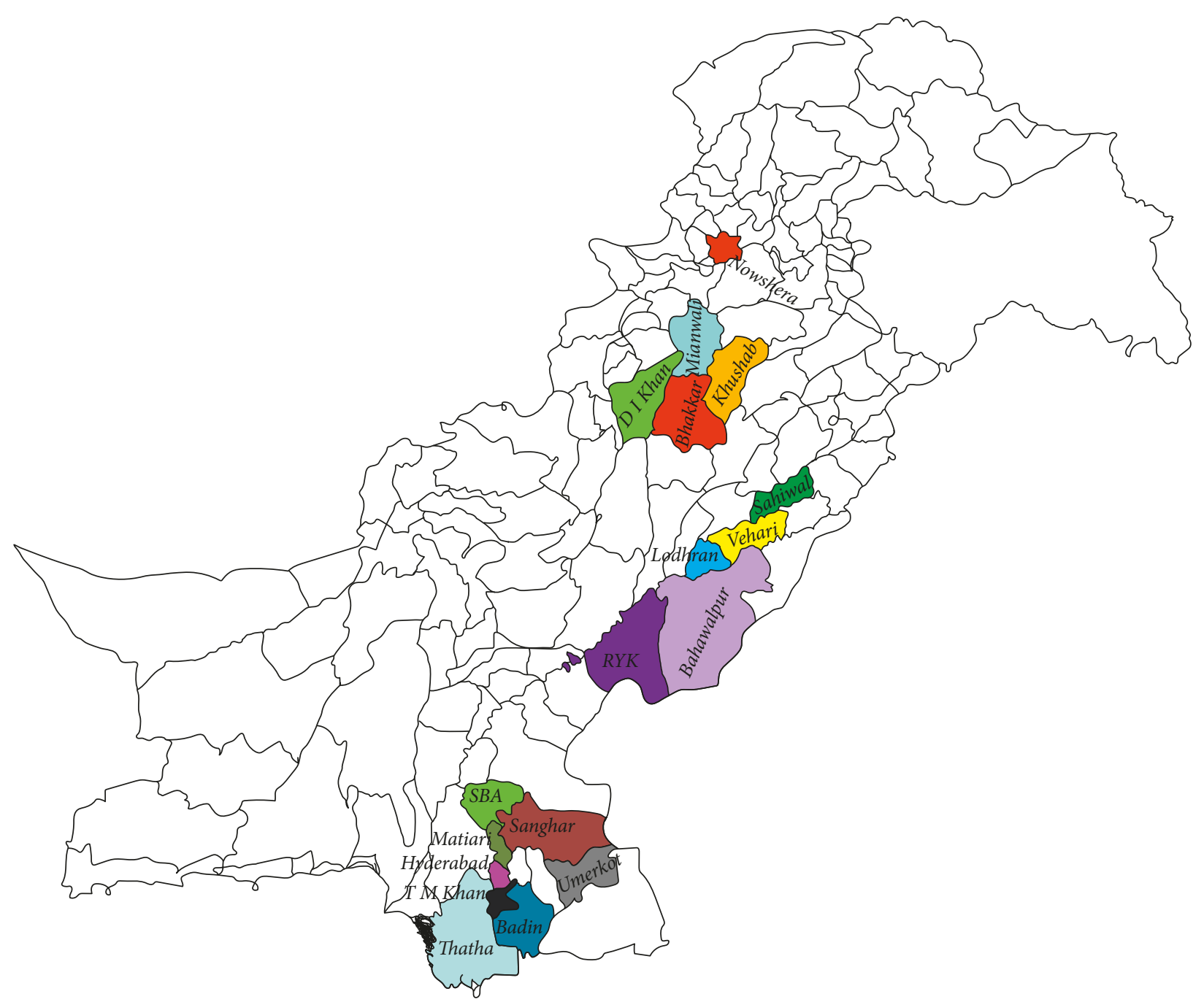

FIgUre 1: Map showing the surveyed and technology evaluation districts in Pakistan.

Khushab, Bhakkar, Mianwali, Vehari, Sahiwal, Bahawalpur, and Lodhran in Punjab Province; Shaheed Benazir Abad, Tando Muhammad Khan, Umerkot, Hyderabad, Matiari, and Sanghar districts in Sind province; and Nowshera and DI Khan districts in Khyber Pakhtunkhwa Province of Pakistan (Figure 1).

These trails were planted in various wheat-based cropping systems of Pakistan that included rice-wheat, cottonwheat, maize-wheat, mung-wheat, and sugarcane-wheat cropping systems. Before planting of wheat, these sites were under either of autumn crops like rice, cotton, maize, sugarcane, millets, and mung. At each site, ridge-furrow planting of wheat was compared with farmers' practice of flat planting. Farmers' practice of wheat planting involved removing of the residue or burning of the residue followed by incorporation of remaining or partially burnt residue with 1-2 passes of rotavator or disc plow. Basal dose of a fertilizer $\left(85 \mathrm{~kg} \cdot \mathrm{P}_{2} \mathrm{O}_{5} / \mathrm{ha}\right.$ and $33 \mathrm{~kg}$ of $\mathrm{N}$ ) in the form of DAP was broadcasted, and fields were prepared with 1-2 operations of the cultivator followed by planking. Afterwards, $125 \mathrm{~kg}$ of the wheat seed per hectare was broadcasted and mixed with one shallow cultivation with planking.
In ridge-furrow planting of wheat, remaining residue after burning or removal was incorporated with the help of 1-2 passes of rotavator or disk plow that was followed by broadcasting of basal dose of the fertilizer $\left(85 \mathrm{~kg} \cdot \mathrm{P}_{2} \mathrm{O}_{5} / \mathrm{ha}\right.$ and $33 \mathrm{~kg}$ of $\mathrm{N}$ ) in the form of DAP and seed bed preparation with 1-2 cultivators and planking. Afterwards, $125 \mathrm{~kg}$ wheat seed per hectare was broadcasted, and ridges with furrows were made through the ridger. During the ridge-furrow making process, most of the seed and fertilizer gathered on ridges and the field is converted into furrow and ridges that is very similar to bed and furrow planting. These ridgers have 3-4 shovels for furrow making, and generally distance between the furrows is around $68-75 \mathrm{~cm}$. Generally, ridges are narrow on the top, whereas the bed is wider than ridges on the top. In some fields, where sowing was done under dry conditions, fields were irrigated in a way that water does not go to top of the ridge and move within the furrow.

In these field trials, $120 \mathrm{~kg} \cdot \mathrm{N}$ and $85 \mathrm{~kg} \cdot \mathrm{P}_{2} \mathrm{O}_{5} / \mathrm{ha}$ in the form of DAP (diammonium phosphate) and urea were applied for wheat crop. All of phosphorus $85 \mathrm{~kg} \cdot \mathrm{P}_{2} \mathrm{O}_{5} / \mathrm{ha}$ and $33 \mathrm{~kg}$ of $\mathrm{N}$ in the form of DAP was applied before planting wheat. However, the remaining $87 \mathrm{~kg}$ of N/ha in the form of 
TABLE 1: Effect of ridge-furrow planting and farmer's practice on wheat grain yield, tillering, and irrigation time.

\begin{tabular}{|c|c|c|c|c|c|c|}
\hline Season & Outcome & Ridge planting & Farmers practice & Difference & $t$-values & Significance \\
\hline \multirow{3}{*}{ 2014-15 } & Yield (kg) & 3939 & 3499 & 440 & 2.04 & $* *$ \\
\hline & Tillers $\left(\mathrm{m}^{-2}\right)$ & 331 & 295 & 36 & 2.67 & $* * *$ \\
\hline & Irrigation time (minutes) & 121 & 186 & -65 & 3.11 & $* * *$ \\
\hline \multirow{3}{*}{$2015-16$} & Yield (kg) & 4146 & 3702 & 445 & 1.92 & $*$ \\
\hline & Tillers $\left(\mathrm{m}^{-2}\right)$ & 337 & 296 & 41 & 2.53 & $* * *$ \\
\hline & Irrigation time (minutes) & 126 & 178 & -52 & -2.47 & $* * *$ \\
\hline
\end{tabular}

Note. The results are significant at ${ }^{* * *} 1,{ }^{* *} 5$, and ${ }^{*} 10 \%$ levels, respectively.

TABle 2: District-wise comparative analysis of grain yield $(\mathrm{kg} / \mathrm{ha})$ from farmer practice and ridge planting of wheat in Pakistan.

\begin{tabular}{|c|c|c|c|c|}
\hline \multirow{2}{*}{ District } & \multicolumn{2}{|c|}{$2014-15$} & \multicolumn{2}{|c|}{$2015-16$} \\
\hline & Farmer practice & Ridge planting & Farmer practice & Ridge planting \\
\hline Badin & 3200 & 3550 & - & - \\
\hline Bahawalpur & 4023 & 4617 & 3908 & 4547 \\
\hline Bhakkar & 2950 & 3263 & 3223 & 3257 \\
\hline DI Khan & 3378 & 3878 & 3756 & 4481 \\
\hline Hyderabad & 4117 & 4567 & 4300 & 4700 \\
\hline Khushab & 2455 & 2677 & 2725 & 2929 \\
\hline Lodhran & 3906 & 4589 & 4648 & 5436 \\
\hline Matiari & 4633 & 5553 & 3867 & 4533 \\
\hline Mianwali & 2549 & 2855 & 3856 & 4007 \\
\hline Nowshera & 2993 & 3077 & - & - \\
\hline Sanghar & 3383 & 3677 & - & - \\
\hline Shaheed Benezirabad & 4400 & 4970 & 3840 & 4560 \\
\hline Sahiwal & - & - & 4150 & 4200 \\
\hline TM Khan & - & - & 3050 & 3550 \\
\hline Thatta & - & - & 3100 & 3800 \\
\hline Umerkot & - & - & 3683 & 4194 \\
\hline Vehari & - & - & 3715 & 3850 \\
\hline Average & 3499 & 3939 & 3702 & 4146 \\
\hline RP-FP (kg/ha) & \multicolumn{2}{|c|}{440} & \multicolumn{2}{|c|}{444} \\
\hline Significance & \multicolumn{2}{|c|}{$* * *$} & \multicolumn{2}{|c|}{$* *$} \\
\hline
\end{tabular}

Note. The results are significant at ${ }^{* * *} 1$ and ${ }^{* *} 5 \%$ levels, respectively.

urea was applied in two equal doses at the first and second irrigation that coincided with crown root initiation and the tillering stage. The data regarding the wheat yield, numbers of tillers, and time needed to irrigate one hectare were collected. Statistical analysis was done using the paired $t$-test between the treatment using Stata version 10.1 software [25].

To document the farmer's perception regarding ridge planting of wheat, a detailed comprehensive survey was carried out and 231 farmers were interviewed to collect information regarding ridge planting of wheat technology, as well as other socioeconomic, household, and farm level characteristics. Before carrying out the formal survey, the pretesting of the questionnaire was carried out and the questionnaire was refined in the light of pretesting results.

\section{Results and Discussion}

Results regarding the ridge-furrow planting effect on the wheat grain yield, numbers of tillers $\mathrm{m}^{-2}$ and time required to irrigate wheat crop for both growing seasons 2014-15 and 2015-16 are presented in Table 1. Average wheat grain yield from all the multilocation trials in 2014-15 and 2015-16 was
$12 \%$ higher with ridge-furrow planting as compared to conventional planting (Table 1).

The detailed analysis of the wheat grain yield in all districts during 2014-15 and 2015-16 showed significant increase in the wheat grain yield with ridge-furrow planting in comparison with farmer's practice (Table 2). Higher wheat grain yield with ridge-furrow planting in all districts under various wheat cropping systems showed that the ridge-furrow planting technique was better than farmer's practice of flat planting in varying soil and climatic conditions (Table 2). The wheat grain yield with ridge-furrow planting was higher than $0.1 \mathrm{t} / \mathrm{ha}$ in all districts except Nowshera in 2014-15 and Bhakkar and Sahiwal in 2015-16. The wheat grain yield was more than $0.5 \mathrm{t} /$ ha in comparison with farmer's practice in districts of Bahawalpur, DI Khan, Lodhran, Matiari, Shaheed Benazir Abad, Umerkot, and Thatta (Table 2).

During 2014-15, the wheat yield was significantly higher with ridge-furrow planting as compared to farmers practice. In ridge-furrow planting, the average difference of $440 \mathrm{~kg} / \mathrm{ha}$ was noted in comparison with farmer practice and the results are significant at the $5 \%$ level of significance (Table 1). This higher yield with ridge-furrow planting was attributed 
to higher numbers of wheat tillers per meter square in ridge planting as compared to farmers practice (Table 1).

During 2015-16, average wheat grain yields were also significantly higher with ridge-furrow planting as compared to farmers practice and the difference in yields was $444 \mathrm{~kg}$ per hectare (Table 1). The grain yield with ridge-furrow planting was higher at $10 \%$ level of significance. Similarly, the number of tillers per unit area was also significantly higher with ridge-furrow planting in comparison with farmer practice in 2015-16 (Table 1). Better tillering and crop growth on ridges during the season contributed to $12 \%$ higher grain yield. Previous studies observed more than $20 \%$ higher grain yield with ridge planting and bed planting in comparison with flat planting $[15,23,24]$.

Furrow-irrigated ridge planting technology helps farmers in saving irrigation water. Average irrigation time for one hectare field under ridge-furrow planting in comparison with farmer practice was 62 and 52 minutes lower in 2014-15 and 2015-16, respectively (Table 1). This reduction in time to irrigate one hectare field of ridge that planted wheat in comparison with farmer practice was highly significant at $1 \%$ level of significance. This showed that ridgefurrow planting helped farmers in saving 29-35\% of water in comparison with farmer practice of flat planting. Farmers applied 4-5 irrigations during wheat growing season, the technology helps farmers in saving 208-260 minutes of irrigation time in a season, and this could also help in reducing energy cost for water pumping. Irrigation water application was also measured with the help of cut throat flume at three farmer fields, and $32-43 \%$ of water saving with ridge-furrow planting in comparison with farmer practice was noted. Raised bed and ridge sowing techniques saved $22 \%$ [23] and $40 \%$ of irrigation water [24] in comparison with flat sowing. The results are also in line with research work $[11,18,19,21]$ who reported saving in irrigation time and water with ridge bed and ridge-furrow methods in comparison with farmer practice.

Because of climate change, the availability of the irrigation water is decreasing, and hence, ridge-furrow planting might help to improve irrigation water use efficiently. In Pakistan, wheat is sown on about 7.8 million hectares under irrigated conditions with average numbers of irrigations in the wheat crop cycle are in the range of $4-5$. The ridgefurrow planting technique helps the farmer in saving $30 \%$ of water and improving $12 \%$ of grain yield in comparison with the prevailing planting technique. The adoption of ridgefurrow or bed furrow on one million hectare area could help to save one million acre foot of water and increase 0.36 million tone in wheat production. This water-saving aspect coupled with the yield increase of $9-12 \%$ is an important driving force for farmers to adopt the technology. If ridge planted wheat yields are equal with farmer practice, even then water saving is also an advantage for the promotion of the ridge planting technology.

The variety-wise comparison of the ridge planting and the conventional planting indicated that the grain yield of different wheat varieties was significantly higher under ridge-furrow planting as compared to farmer practice (Table 3).
TABLE 3: Effect of ridge planting and farmer practice on grain yield $(\mathrm{kg} / \mathrm{ha})$ of wheat varieties in 2014-15 and 2015-16.

\begin{tabular}{lcccc}
\hline Wheat variety & $\begin{array}{c}\text { Ridge } \\
\text { planting }\end{array}$ & $\begin{array}{c}\text { Farmer } \\
\text { practice }\end{array}$ & Difference & Significance \\
\hline AARI-2011 & 2733 & 2503 & 230 & $* *$ \\
Lasani-2008 & 2797 & 2542 & 255 & $* *$ \\
Punjab-2011 & 3112 & 2877 & 235 & $* *$ \\
Imdad-2005 & 3900 & 3300 & 600 & $* * *$ \\
NARC-2011 & 4400 & 3600 & 800 & $* * *$ \\
Pakistan- & 4200 & 3650 & 550 & $* * *$ \\
2013 & 4000 & 3475 & 525 & $* * *$ \\
TD-1 & 4463 & 3944 & 519 & $* * *$ \\
Benazir-2013 & 3337 & 3117 & 220 & $* *$ \\
Millat-2011 & &
\end{tabular}

Note. The results are significant at ${ }^{* * *} 1$ and ${ }^{* *} 5 \%$ levels, respectively.

Wheat g1rain yields was highest with Benazir-2013 and lowest with AARI-2011. Wheat varieties Imdad-2005, NARC-2011, Pakistan-2013, TD-1, and Benazir-2013 had $525-800 \mathrm{~kg} / \mathrm{ha}$ higher grain yield with ridge-furrow planting in comparison with farmer practice. However, wheat Millat2011, Punjab-2011, AARI-2011, and Lasani-2008 had 220$255 \mathrm{~kg} / \mathrm{ha}$ higher wheat grain yield with ridge-furrow planting in comparison with farmer practice. For all these wheat varieties, the grain yields were higher for the ridge planting technology followed by the farmers practice. Higher wheat grain yield of wheat varieties Imdad-2005, NARC2011, Pakistan-2013, TD-1, and Benazir-2013 on ridges might be due to better tillering and better growth under raised bed condition in comparison with flat planting. These wheat varieties could have better ground cover and broad leaf area that might have contributed to better grain yield in comparison with other varieties with erect and compact structure [10].

3.1. Farmer Survey on Ridge-Furrow Planting. Field level data were also supplemented by the farmer's survey data regarding farmer perception of the ridge planting technology, technology feasibility (cost benefit ratios), and constraints in the adoption of the technology.

The empirical results regarding adoption of the ridge planting technology are presented in Table 4 . Analysis of the results showed that educated, young farmers with large land holding and tube well adopted ridge planting of wheat technology (Table 4). In this model, the dependent variable is technology adoption, that is, Score 1, if the farmers adopt the ridge planting technology and score 0 , otherwise. A set of independent variables are included in the model.

The age was included in the numbers of years with a negative coefficient indicating that mostly the young farmers adopted ridge planting technology. The education was also included in the numbers of years with a positive coefficient with significance at $1 \%$ level which indicated that mostly the educated farmers have adopted the ridge planting technology. The family size coefficient is positive and nonsignificant. The land holding coefficient was positive and highly significant at $1 \%$ level of significance indicating that mostly the larger farmers have adopted the ridge planting 
TABLE 4: Determinants of the ridge planting technology adoption (profit estimates).

\begin{tabular}{lcc}
\hline Variable & Coefficient & $t$-values \\
\hline Age & $-0.07^{* *}$ & -2.15 \\
Education & $0.03^{* * *}$ & 2.78 \\
Family size & 0.02 & 1.44 \\
Land holding & $0.01^{* * *}$ & 2.59 \\
Agriculture extension & 0.02 & 1.36 \\
Credit & 0.04 & 1.28 \\
Car & 0.06 & 1.44 \\
Tractor & $0.01^{* *}$ & 2.10 \\
Tube well & $0.02^{*}$ & 1.45 \\
Constant & 0.03 & 1.57 \\
Number of observations & & 138 \\
Pseudo R-square & \multicolumn{2}{c}{0.37} \\
LR-chi-square & \multicolumn{2}{c}{283.57} \\
Probability > chi-square & \multicolumn{2}{c}{0.000} \\
\hline
\end{tabular}

Note. The results are significant at ${ }^{* * *} 1,{ }^{* *} 5$, and ${ }^{*} 10 \%$ levels, respectively.

technology. Agriculture extension, credit, and ownership of car are positive and nonsignificant. The tractor and tube well coefficients were significantly positive indicating that farmers having tractor and tube well ownership were mostly adopting the ridge planting technology. Farmer with tube well for irrigation not only got benefit of water saving but also reduced energy cost per hectare. The R-square value 1 was 0.37 indicating that $37 \%$ variation in the dependent variable is due to independent variables included in the model. The LR chi square is highly significant at $1 \%$ level of significance indicating the robustness of the variables included in the model.

3.2. Benefit Cost Analysis of Ridge-Furrow Planting. Benefit cost analysis of wheat crop sown by the conventional method and ridge planting showed that ridge planting of wheat was a profitable technique for farmers in comparison with the conventional planting technique (Table 5).

$$
\text { Benefits cost ratio }(\mathrm{BCR})=\frac{\mathrm{PV}_{\text {Benefits }}}{\mathrm{PV}_{\text {Costs }}},
$$

where $\mathrm{PV}_{\text {Benefits }}=$ present value of benefits and $\mathrm{PV}_{\text {Costs }}=$ present value of costs.

The results showed that the average land preparation cost for ridge planting adopter and conventional farmers was USD/ha 105.61 and 103.74, respectively. Seed cost for ridge growers and conventional farmers was determined as USD/ha 61.68 and 56.07, respectively. Ridge planting adopters use $12.5 \mathrm{~kg} / \mathrm{ha}$ more seed in comparison with nonadopter to improve crop stand. Planting cost for ridge planting farmers and conventional farmers was determined as USD/ha 23.36 and 12.85 , respectively. In ridge planting, farmer used the ridger for making furrow and ridges, so the planting cost for the ridge was higher (USD 10.51/ha) in comparison with farmer practice (Table 5). Wheat growers applied DAP and urea fertilizer to meet phosphorus and nitrogen demand of the wheat crop, and the cost of fertilizer application was same for both methods. Weedicide application and irrigation cost for the beneficiary farmer was USD
TABle 5: Details regarding cost of production and cost benefit analysis of ridge planting and farmer practice in USD per hectare.

\begin{tabular}{lccc}
\hline Input $\left(\mathrm{USD} \mathrm{ha}^{-1}\right)$ & $\begin{array}{c}\text { Ridge } \\
\text { planting }\end{array}$ & Farmer practice & Ridge-FP \\
\hline Land preparation cost & 105.61 & 103.74 & 1.87 \\
Seed cost & 61.68 & 56.07 & 5.61 \\
Planting cost & 23.36 & 12.85 & 10.51 \\
Fertilizer cost & 239.25 & 240.11 & -0.86 \\
Weedicide cost & 16.79 & 18.97 & -2.18 \\
Irrigation cost & 21.03 & 26.28 & -5.25 \\
Harvesting cost & 83.71 & 72.54 & 11.17 \\
Production cost-total & 551.44 & 530.57 & 20.87 \\
Wheat yield (kg/ha) & 34.11 & 30.37 & 3.74 \\
Wheat price (USD/kg) & 0.30 & 0.30 & 0.00 \\
Gross revenue wheat & 1108.64 & 987.15 & 121.50 \\
Net revenue (profit) & 557.21 & 456.58 & 100.63 \\
Cost benefit ratio & 2.01 & 1.86 & \\
\hline
\end{tabular}

Note. One USD (United States dollar) is equal to 107 PKR (Pakistani rupees).

16.79 and 21.03 per hectare that was lower than the nonbeneficiary farmers. Harvesting cost in the beneficiary case was recorded USD 83.71 that was higher than the conventional technique farmers. Harvesting charges through combine harvestor or manual labor were higher for ridgefurrow planted wheat in comparison with farmer practice. This is the perception of service providers that there could be more wear and tear of machinery on ridges or raised beds. Total wheat production for ridge farmers was USD 551.44/ha that was higher as compared to nonadopter cost of USD $530.57 /$ ha. However, ridge planting adopters had a wheat grain yield of $3650 \mathrm{~kg} / \mathrm{ha}$ that was better than the nonadopter yield of $3250 \mathrm{~kg} / \mathrm{ha}$. This was also in line with the trial data of both years that showed that wheat yields were higher on ridges in comparison with wheat planted on flat surface. Overall profit was USD 557.21 and 456.58 per hectare in beneficiary and nonbeneficiary case, respectively. In these analysis, farmer management cost and rent of land were not included in the cost of production, and farmers were able to get USD 100.63 per hectare more net profit with ridgefurrow planting of wheat in comparison with farmer practice. Raised bed planting under the ZT condition had 13-28\% higher system productivity and net return of USD 312 ha-1 in comparison with the conventional planting system $[13,14,20]$.

Ridge-furrow planting adopter farmers paid additional cost of USD 17.29 ha for extraseed, ridge making, and harvesting charges in comparison with nonadopters. However, adopters saved USD 5.25/ha from irrigation cost when they used tube well for irrigation once in the season. In addition, they also saved time for the irrigating field. The cost benefit analysis indicates that ridge planting is more profitable as compared to the conventional method of planting. The cost benefit ratio for the ridge planting is well above 2 , while for the conventional planting method, its only 1.86 .

There are a number of constraints enlisted by farmers in adopting ridge planting of wheat. The most important is the lack of awareness, the efficient extension services, as well as the low availability of ridgers with service providers at village level. 
Some of the adopting farmers think that combine harvesting on ridge planted wheat is an issue, and service providers avoid those field because of fear to damage to combine harvest. In this process, serviced providers delay the harvesting of these fields and usually agree for harvesting at the end of season with higher charges.

\section{Conclusions}

Ridge planting of wheat in an irrigated area of Pakistan helped farmers to obtain 12\% higher wheat grain yield and $30-35 \%$ water saving and ease in irrigation management in comparison with farmer practice. Educated farmers with sizable land holding and tube well are the initial adopter of technology for its simplicity and availability of ridgers at farm level, water saving, and better yield. Ridge-furrow planting not only saves water but also improves drainage in the event of heavy rainfall during wheat season. The ridge-furrow planting is being demonstrated to the farming community through active involvement of Department of Agriculture Extension Punjab in the cotton-wheat and rice-wheat system. The adoption of ridge planting on one million hectare area could help to save one million acre foot of water that can be used to irrigate more area. In addition, it could also help in producing 0.36 million tons of additional wheat grain per year. Farmer community moving from flat planting to ridge planting also provides an opportunity for transforming ridge planting farmers into users of mechanized bed planting with planting, bed making, and fertilizer application in one operation and could also help in reducing cost and improving fertilizer use efficiency at farmer fields in future. Precision planting can make inroad with the availability of suitable bed and furrow planter that can plant wheat in residue of preceding crop like cotton, maize, and rice. Agricultural extension needs to create awareness and build capacity regarding this important technology in Pakistan.

\section{Data Availability}

The data related to this manuscript is available upon request.

\section{Conflicts of Interest}

The authors declare that there are no conflicts of interest regarding the publication of this paper.

\section{Acknowledgments}

The research work was carried out under Agricultural Innovation Program (AIP) for Pakistan funded by USAID.

\section{References}

[1] Government of Pakistan, Pakistan Economic Survey 2016-17, Economic Adviser's Wing, Finance Division, Government of Pakistan, Islamabad, Pakistan, 2017.

[2] D. Byerlee, P. R. Hobbs, B. R. Khan, A. Majid, R. Akhtar, and N. I. Hashmi, Increasing Wheat Productivity in the Context of Pakistan's Irrigated Cropping Systems, PARC/CIMMYT, Islamabad, Pakistan, 1986.
[3] M. A. Khan, Wheat Crop Management for Yield Maximization, Vol. 44, Wheat Research Institute, Faisalabad, Pakistan, 2003.

[4] I. Hussain, H. Shah, M. A. Khan, W. Akhtar, A. Majid, and M. Y. Mujahid, "Productivity in rice-wheat crop rotation of Punjab: an application of typical farm methodology," Pakistan Journal of Agricultural Research, vol. 25, pp. 1-11, 2012.

[5] K. D. Sayre and O. H. Mreno-Ramos, Application of Raised Bed Planting System to Wheat, Wheat Program Special Report No. 31, CIMMYT, Mexico, DF, Mexico, 1997.

[6] P. R. Hobbs, K. D. Sayre, and J. I. Ortiz-Monasterio, Increasing Wheat Yields Sustainably through Agronomic Means, CIMMYT NRG Paper, Mexico, DF, Mexico, 1998.

[7] R. J. Connor, J. Timsina, and E. Humphreys, "Prospects for permanent beds in the rice-wheat system," in Improving the Productivity and Sustainability Of Rice-Wheat System: Issues and Impacts, pp. 197-210, ASA Inc., CSSA Inc., SSSA Inc., Madison, WI, USA, 2003.

[8] B. U. Choudhury, B. M. Bouman, and A. K. Sigh, "Yield and water productivity of rice-wheat on raised beds at New Delhi, India," Field Crops Research, vol. 100, no. 2-3, pp. 229-239, 2007.

[9] B. Govaerts, K. D. Sayre, J. M. Ceballos-Ramirez et al., "Conventionally tilled and permanent raised beds with different crop residue management: effects on soil $\mathrm{C}$ and $\mathrm{N}$ dynamics," Plant and Soil, vol. 280, no. 1-2, pp. 143-155, 2006.

[10] H. Kiliç, "The effect of planting methods on yield and yield components of irrigated spring durum wheat varieties," Scientific Research and Essays, vol. 520, pp. 3063-3069, 2010.

[11] A. Majid, A. Muhmood, A. Niaz et al., "Bed planting of wheat (Triticum aestivum L.) improves nitrogen use efficiency and grain yield compared to flat planting," Crop Journal, vol. 3, pp. 118-124, 2015.

[12] F. Wang, W. Xuqing, and K. Sayre, "Comparison of conventional, flood irrigated, flat planting with furrow irrigated, raised bed planting for winter wheat in China," Field Crops Research, vol. 87, pp. 35-42, 2004.

[13] C. M. Parihar, S. L. Jat, A. K. Singh et al., "Conservation agriculture in irrigated intensive maize-based systems of north-western India: effects on crop yields, water productivity and economic profitability," Field Crops Research, vol. 193, pp. 104-116, 2016.

[14] R. D. Jat, H. S. Jat, R. K. Nanwal et al., "Conservation agriculture and precision nutrient management practices in maize-wheat system: effects on crop and water productivity and economic profitability," Field Crops Research, vol. 222, pp. 111-120, 2018.

[15] R. A. Mann and C. A. Meisner, Proceedings of the National Workshop on Rice-Wheat Systems in Pakistan, A Rice Wheat Consortium Paper Series 15, p. 118, Islamabad, Pakistan, 2003.

[16] M. I. U. Mollah, M. S. U. Bhuiya, M. S. Hossain, and S. M. A. Hossain, "Growth of wheat (Triticum Aestivum L.) under raised bed planting method in rice-wheat cropping system," Journal of Agriculture \& Rural Development, vol. 7, pp. 23-31, 2015.

[17] E. A. Waraich, R. Ahmad, and S. Ahmad, "Raised bed planting-a new technique for enhancing water use efficiency in wheat (Triticum aestivum L.) in semi-arid zone," Iranian Journal of Plant Physiology, vol. 1, pp. 73-84, 2010.

[18] N. Ahmad and N. Mahmood, "Impact of raised bed technology on water productivity and logging of wheat," Pakistan Journal of Water Resources, vol. 90, pp. 7-15, 2005.

[19] M. A. Shahid, N. Ahmad, M. Saleem, and B. Akhtar, "Investigating optimum number of irrigations for wheat under 
raised bed Technology in a semi-arid climate," International Journal of Applied Agricultural Sciences, vol. 3, pp. 89-93, 2011.

[20] M. A. Shahid, N. Ahmad, M. Arshad, and M. Usman, "Enhancing land and water productivity through furrow irrigated raised bed planting-a case study of underutilized lands in Pakistan," Pakistan Journal of Agricultural Sciences, vol. 52, pp. 981-988, 2015.

[21] I. Hassan, Z. Hussain, and G. Akber, "Effect of permanent raised beds on water productivity for irrigated maize-wheat cropping system. Evaluation and performance of permanent raised bed cropping system in Asia, Australia and Mexico" in ACIAR Proceedings, C. H. Roth, R. A. Fischer, and C. A. Meisner, Eds., vol. 121, pp. 59-65, January 2005.

[22] S. U. Khan and K. Ullah, "Effect of various planting methods on seed cotton yield," Pakistan Cottons, vol. 35, no. 1 , pp. 43-47, 1991.

[23] M. Ali, L. Ali, M. Q. Waqar, and M. A. Ali, "Bed planting: a new crop establishment method for wheat (Titicum aestivum L.) in cotton-wheat cropping system of southern Punjab," International Journal of Applied Agricultural Sciences, vol. 4, pp. 8-14, 2012.

[24] M. Akhtar, M. Aslam, H. M. Nasrullah, B. Ali, and M. A. Khan, "Effect of ridge sowing methods on wheat yield in cotton-wheat cropping system of southern Punjab," Journal of Rural Development, vol. 45, pp. 29-39, 2014.

[25] C. A. Cameron and P. K. Trivedi, Micro Econometrics Using Stata, Stata Press, College Station, TX, USA, 2009. 


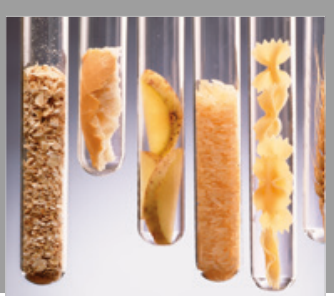

International Journal of Food Science

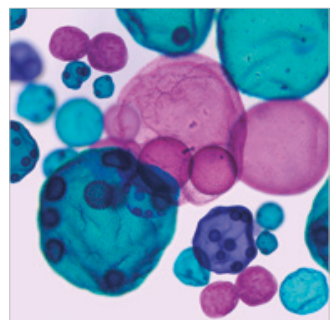

International Journal of Microbiology
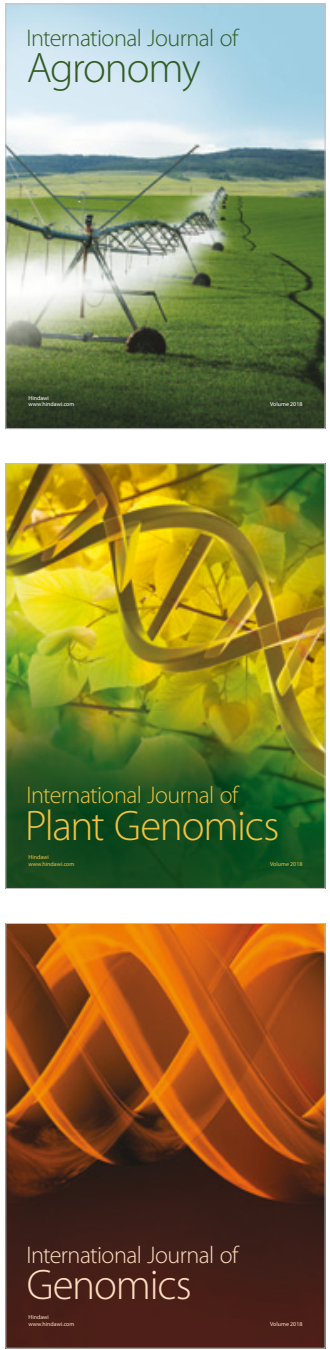

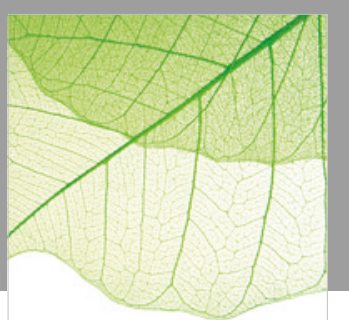

Journal of Botany
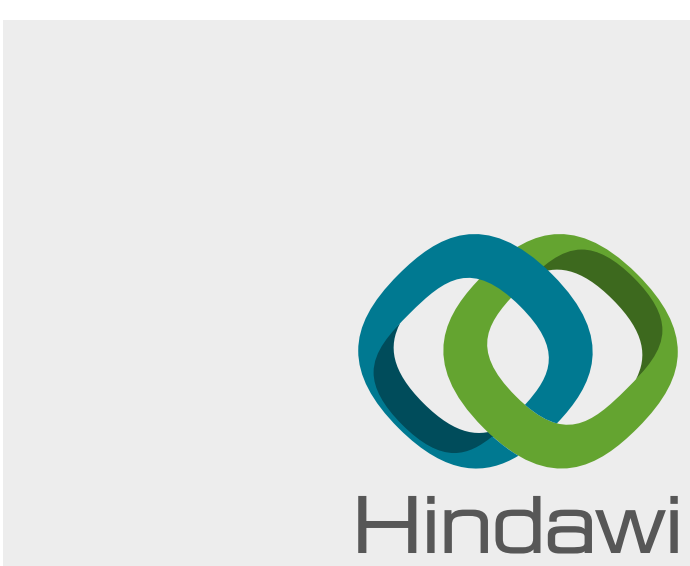

Submit your manuscripts at

www.hindawi.com
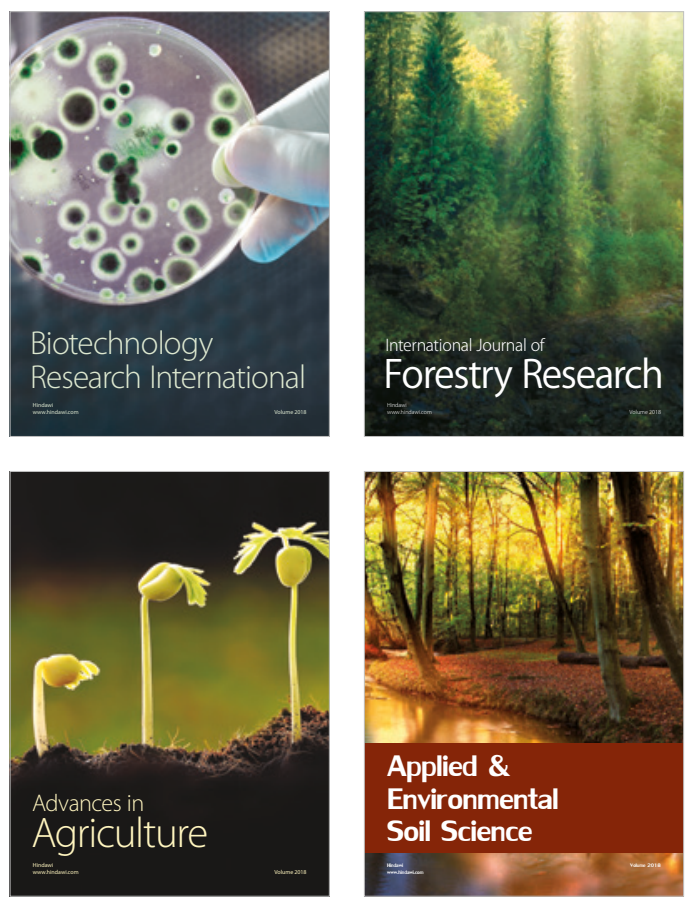

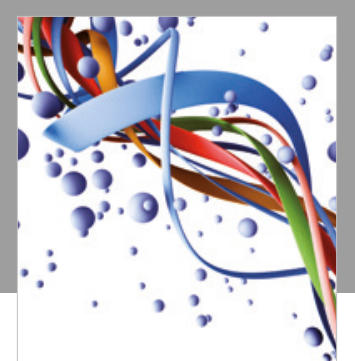

Scientifica

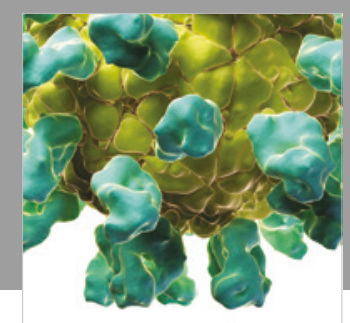

Veterinary Medicine International

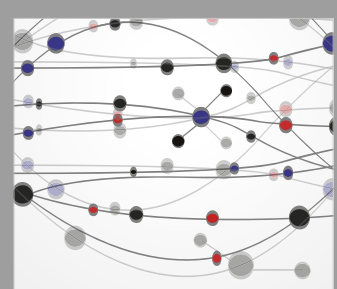

The Scientific World Journal
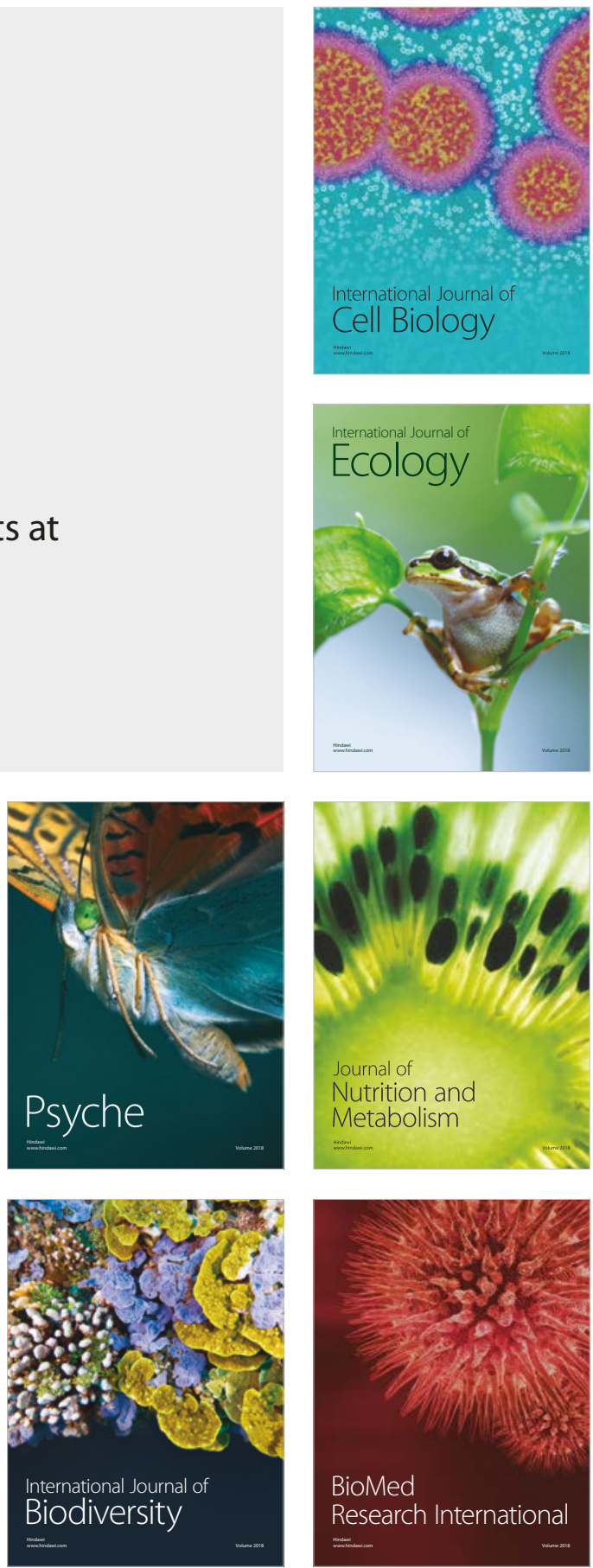